\title{
Perlindungan Hukum terhadap Masyarakat Akibat Pemberitaan Pers
}

\author{
Samsul Wahidin
}

\begin{abstract}
The reformation of the mass media, especially printed press, in Indonesia has already caused a new paradigm of freedom of press. In one hand, the press freedom is a reflection of the freedom of expressing ideas and of obtaining information, which is assured by the constitution. This press freedom, however, is always put forward by joumalists as one of the element of democratic principles. On the other hand, the freedom face problems of urgently required legal protection to societies as the consequence of the invalid press release. As a result, the press arrogance emerges. The legal protection toward the press release victims requires taking a tes in practice as a balance of the press freedom.
\end{abstract}

\section{Pendahuluan}

Era reformasi telah membuka kesempatan yang luas kepada masyarakat dalam bidang informasi, untuk mengekspresikan diri baik sebagai pemberi maupun pengakses informasi. Sebagai pemberi informasi, masyarakat dapat mengusahakan hal tersebut melalui pengelolaan media massa khususnya pers cetak. $^{1}$
Perkembangan pesat media pemberi informasi dewasa ini telah meletakkan pers sebagai salah satu sektor komoditas yang dikelola dengan teknologi tinggi (high technology). Pers merupakan sektor teknologi sekaligus ekonomi yang dalam operasionalisasinya bersentuhan dengan sisi sosial kemasyarakatan yang luas. ${ }^{2}$

'Mustafa Abdullah. 1988. Sistem Pertanggungjawaban Pidana Pers Menurut Hukum Positif Indonesia. Pidato Pengukuhan Guru Besar Fak. Hukum Univ. Sriwijaya, membedakan pers dalam arti sempit dan arti luas. Dalam arti sempit adalah media tercetak khususnya surat kabar.

${ }^{2}$ Tentang ini lihat misalnya dalam Arnold Pacey. 1983. The Culture of Technology. (Cambridge Massachusetts: The MIT Press. 
Dari sisi ekonomis, pers telah menjadi sebuah lahan bisnis yang mampu menjanjikan keuntungan dalam jumlah besar bagi pemodalnya. Oleh karena itu, pemerintah juga merasa berkepentingan untuk mengatur kehidupan pers agar tidak mendatangkan masalah baik bagi masyarakat maupun bagi pemerintah sendiri. Namun, pengaturan demikian pada akhimya hanya bersifat delegation principle yaitu dengan menyerahkan kewenangan untuk pengawasan pers terhadap masyarakat dan intern pers itu sendiri.

Sebagai pengakses informasi, akibat dari begitu banyaknya media pasca reformasi itu pula, masyarakat mempunyai banyak pilihan media yang sesuai dengan selera dan kepentingannya. Legalitas untuk mengakses informasi, sebagai refleksi dari hak asasi manusia juga menjadi titik perhatian Majelis Permusyawaratan Rakyat (MPR) dalam sidang umum 1998. Di dalam sidang umum tersebut telah diakomodasi hak masyarakat untuk memperoleh dan mengakses informasi itu sebagai bagian tak terpisahkan dari pemenuhan hak asasi manusia. ${ }^{3}$

Oleh sebab itu hak untuk mengakses informasi ini juga dituangkan dalam Tap No. XVII/MPR/1998 tentang Hak Asasi Manusia. Untuk dapat memperoleh kebulatan hubungan yang menyeluruh, maka dalam tiap Tap itu disertai lampiran yang berisi pandangan dan sikap bangsa Indonesia terhadap HAM dan piagam HAM. Dalam Bab IV tentang hak atas kebebasan informasi, menyatakan sebagai berikut:
Setiap orang berhak untuk berkomunikasi dan memperoleh informasi untuk mengembangkan pribadi dan lingkungan sosialnya. (Pasal 20)

Setiap orang berhak untuk mencari, memperoleh, memiliki dan menyimpan, mengolah dan menyampaikan informasi dengan menggunakan segala jenis saluran yang ada. (Pasal 21)

Ekspresi kebebasan untuk menyalurkan informasi itu ternyata juga berbenturan dengan masalah lain misalnya tentang hak pribadi untuk tidak diberitakan. Demikian pula, penyaluran informasi, kendatipun dilandasi oleh iktikad untuk menyampaikan informasi kepada masyarakat dapat berbenturan dengan kepentingan umum.

Dalam bentuk yang lebih konkret, penyaluran informasi yang berwujud dalam media cetak (pers) itu ternyata tidak selalu mulus dalam arti tidak bermasalah dalam pengelolaannya. Hal ini khususnya sebagai akibat dari persaingan media cetak, yang mengharuskan pengelolanya yang berlindung di balik kebebasan untuk menyampaikan informasi tersebut bersaing dengan sesamanya sehingga mendatangkan masalah baru yaitu munculnya pemberitaan pers yang dirasakan tidak sesuai dengan kenyataan. Apabila hal itu terjadi, maka akan dapat mendatangkan kerugian khususnya kerugian moral pada warga masyarakat baik yang menjadi objek berita maupun yang secara tidak langsung berhubungan dengan berita tersebut. Permasalahannya adalah bagaimanakah perlindungan hukum terhadap

${ }^{3}$ Mulya Lubis. 1986. "Realitas Hak untuk Mendapatkan informasi dan Berkomunikasi di Indonesia". Hukum dan Pembangunan No. 4 Tahun XV. HIm. 34. 
masyarakat sehingga sesuai dengan misi yang diemban pers yaitu menyampaikan informasi secara objektif.

\section{Perlindungan Hukum Pers}

Perlindungan hukum ${ }^{4}$ yang dimaksud di sini adalah upaya yang seharusnya ditempuh untuk mencegah munculnya arogansi pers yaitu tindakan pers yang tidak profesional. Julukan ini ditujukan untuk praktik pengelolaan pers yang mengedepankan keuntungan ekonomis dengan mengeksploitasi berita. Berita dikemukakan bukan sebagai refleksi hak untuk menyalurkan informasi tetapi sebagai komoditas dengan rekayasa yang tidak proporsional dengan motivasi agar lebih laku.

Dalam perspektif pers, tidak sederhana untuk mengenali standar normatif dalam masyarakat, sebagai ukuran dapat atau tidaknya sebuah berita disajikan. Satu dan lain hal, standar normatif tersebut sifatnya memang abstrak dan berubah dari waktu ke waktu. ${ }^{5}$ Kendatipun refleksi dari standar normatif ini juga sudah disebut dalam peraturan perundangundangan, tetapi masih dan bahkan sering terjadi pelanggaran yang menyangkut seseorang atau sekelompok orang. Penyebab dari hal ini di samping karena keterbatasan waktu, keharusan untuk memenuhi target berita $^{6}$ bagi seorang wartawan, juga pemahaman terhadap peraturan perundangundangan yang tidak sama terhadap pemberitaan yang menimbulkan kerugian tersebut, atau bisa juga hal itu disebabkan oleh ketidakmautahuan wartawan terhadap peraturan perundangan yang seharusnya dijadikan landasan hukum untuk melaksanakan tugasnya.

Dalam soal kinerja pers, sebuah pemberitaan dapat disajikan tentu setelah memenuhi standar normatif di masyarakat di mana pers itu berada (dalam ukuran pers).

Kendatipun dalam perspektif pihak yang merasa dirugikan dapat dianggap sebagai melanggar standar normatif. Di sini ada relativitas nilai yang disadari sifatnya memang abstrak. Sementara pada siși lain persepsi seseorang atau sekelompok orang yang menjadi objek atau sumber berita tidak sama. Suatu pemberitaan dapat dinilai mencemarkan nama baik, memfitnah dan atau merupakan sajian yang sifatnya destruksi bahkan dapat diancam dengan ketentuan pidana menurut seseorang, tetapi belum tentu pandangan itu sama dengan orang lain. Orang lain akan bisa jadi mempunyai persepsi yang berbeda.

Hal di atas juga membawa akibat pada mekanisme penyelesaian yang akan ditempuh. Ada yang menempuhnya melalui mekanisme yang bersifat standar yaitu memfungsikan hak $\mathrm{jawab}^{7}$ dan masalahnya dianggap selesai

4Perlindungan hukum (legal protection) lazimnya berhubungan dengan kekuasaan pemerintah. Namun kekuatan yang dilindungi hukum juga dapat melakukan hal yang sama kepada yang lemah. Lihat Philipus M Hadjon. 1987. Perlindungan Hukum Bagi Rakyat di Indonesia. Surabaya: Bina IImu. HIm. 1.

${ }^{5}$ Ashadi Siregar. 1987. Ilusi Sebuh Kekuasaan. Surabaya; ISEI dan PUSHAM Ubaya. HIm. 5.

"Istilah dikalangan pers adalah deadline (tenggat) merupakan batas waktu yang tidak bisa lagi ditawar untuk sebuah berita untuk diproses lebih lanjut sehingga siap dicetak dan didistribusikan.

${ }^{7} \mathrm{Hak}$ Jawabmerupakan hak yang diakomodasikan oleh UU kepada khalayak yang menilai bahwa suatu pemberitaan tidak benar. Dalam batas kewajaran, redaksi harus memuat penjelasaan tersebut. 
namun juga ada yang merasa tidak cukup dengan cara demikian dan memilih penyelesaian melalui upaya hukum yaitu melalui peradilan pidana dan atau peradilan perdata. Hal demikian sesuai dengan jalur penyelesaian yang dapat ditempuh sesuai dengan peraturan perundang-undangan.

Alur menurut hukum pidana yang biasanya ditempuh oleh pihak yang merasa dirugikan pemberitaan pers adalah melalui hukum pidana. Dalam hal ini ketentuan formal yang dijadikan sebagai landasan formal (Hukum Acara) adalah KUHAP sedangkan hukum materiilnya adalah UU Pokok Pers sesuai dengan asas lex specialis derogat legigenerali (ketentuan yang khusus mengenyampingkan ketentuan yang sifatnya umum. ${ }^{8}$ Sehubungan dengan pengaduan terhadap pers dalam perkara pidana ini, maka menurut KUHAP jalumya adalah sebagai berikut:

a. Pihak yang merasa dirugikan melaporkan kasus yang menimpanya ke penyidik. Hal ini sesuai dengan ketentuan bahwa yang berwenang menerima laporan dan selanjutnya melakukan penyidikan termasuk delik pers (Pasal $7 \mathrm{~s} / \mathrm{d}$ Pasal 12 KUHAP).

b. Penyidik melimpahkan kasus itu ke Penuntut Umum setelah memenuhi syaratsyarat pelimpahan penyidikan (Pasal 15 KUHAP)

c. Penuntut Umum melakukan penuntutan dengan membawa perkara itu ke pengadilan dengan terdakwa sesuai ketentuan Pasal 15 ayat (1) UU Pokok Pers (Pasal 84 dan seterusnya KUHAP).
Dalam hal ada laporan kepada penyidik, idealnya harus segera ditindaklanjuti dengan memanggil para pihak yang berhubungan dengan kasus tersebut untuk memperoleh kejelasan duduk perkaranya (Pasal 7 huruf e, g, h KUHAP) dan kalau memang tidak memenuhi syarat harus segera menghentikan penyidikan (Pasal 7 huruf I). Proses berdasarkan KUHAP ini tentu saja dimaksudkan sebagai upaya yang harus ditempuh demi sebagai tegaknya hukum dan keadilan yang merupakan refleksi penegakan HAM.

Dari prediksi ketentuan dalam KUHAP di atas, tidak terkandung adanya konsekuensi apalagi sanksi yang harus dipikul oleh penyidik manakala dalam proses penyidikan itu berjalan lambat. Atau bahkan penyidik tidak menindaklanjuti laporan yang disampaikan sesuài dengan kewenangannya. Hal ini membawa konsekuensi penyidik dapat mengabaikan laporan atau pengaduan yang disampaikan kendatipun idealnya harus segera ditindaklanjuti. Dalam hal ini tidak ada rentang waktu yang sifatnya limitatif dalam KUHAP untuk penanganan sebuah pengaduan, apalagi konsekuensi atau sanksi atas tidak segera ditanganinya pengaduan itu.

Berdasarkan ketiadaan batas waktu ini, penyidik dapat bersifat tak acuh dengan kasus yang seharusnya segera ditangani sesuai KUHAP dengan berbagai motivasi. Di antara motivasi yang menonjol adalah terjadinya konspirasi dengan pers, seperti terpola dalam bentuk kemitraan antara POLRI dan wartawan, adanya kepentingan penyidik

Wina Armada. 1993. Menggugat kebebasan Pers. Jakarta: Pustaka Sinar Harapan. Him. 37. 
dengan publikasi yang untuk efektifnya hanya dapat dilakukan oleh wartawan, dan sebagainya. Keadaan di atas menyebabkan penyidik enggan melakukan pemanggilan kepada pihak yang terkait dengan pengaduan terhadap pers apalagi menindaklanjuti ke proses penuntutan.

Tindakan yang muncul ke permukaan adalah dengan membiarkan kasus itu mengambang dan berlalu sehingga pihak yang merasa dirugikan akan kelelahan sendiri menunggu kasusnya yang tak kunjung ditangani oleh penyidik. Dalam hubungan inilah, relevan sekali adanya pengaturan tentang batas waktu bagi kinerja penyidik untuk melindungi hak-hak yang merasa dirugikan.

Dengan berakhirnya rentang waktu tersebut penyidik harus menentukan sikap berdasarkan prinsip administratif penyidikan apakah kasusnya dapat diteruskan atau dihentikan. Dengan demikian pihak yang merasa dirugikan dapat mengambil sikap berdasarkan keterangan dari penyidik tersebut. Kiranya masalah rentang waktu itu layak dimasukkan dalam KUHAP sebagai jaminan rasa keadilan dan kepastian hukum khususnya pihak yang menjadi korban pemberitaan pers yang tidak benar. Harus disadari bahwa penyidik dalam hal ini memegang peran penting dalam kedudukannya sebagai pengawal dan penegak hukum untuk menindaklanjuti pengaduan dari pihak yang merasa dirugikan. Oleh sebab itu kesungguhan aparat penegak hukum, khususnya penyidik amat penting untuk menanggapi secara wajar dan berkeadilan tiap pengaduan yang disampaikan melalui instansi tersebut.
Dalam hal hukum pidana materiil, kendatipun ketentuan yang dilanggar itu disebutkan dalam KUHP namun penyidik harus berpegang pada UU Pokok Pers. Pada masa lalu ternyata pertanggungjawaban yang didasarkan pada konsep suksesif Pasal 15 ayat 4 UU No. 21 tahun 1982 sulit untuk dioperasionalkan. Secara garis besar pertanggungjawaban berdasarkan UU tersebut ialah:

1. pemimpin umum bertanggung jawab atas keseluruhan penerbitan ke dalam maupun ke luar;

2. pertanggungjawaban pemimpin umum terhadap hukum dapat dipindahkan kepada pemimpin redaksi atas pelaksanaan redaksional dan kepada pemimpin perusahaan mengenai soal-soal perusahaan;

3. pemimpin redaksi bertanggung jawab atas pelaksanaan redaksional dan wajib melayani hak jawab dan koreksi yang diminta;

4. pemimpin redaksi dapat memindahkan pertanggungiawaban terhadap hukum mengenai suatu tulisan kepada anggota redaksi atau penulis yang bersangkutan;

5. dalam pertanggungjawaban suatu tulisan terhadap hukum pemimpin redaksi, anggota redaksi atau penulisnya mempunyai hak tolak;

6. wartawan, yang karena pekerjaannya mempunyai kewajiban menyimpan rahasia dalam hal ini nama, jabatan, alamat atau identitas lainnya dari orang yang menjadi sumber informasinya mempunyai hak tolak; 
7. ketentuan tentang hak tolak akan diatur oleh pemerintah setelah mendengar pertimbangan dari Dewan Pers. ${ }^{9}$

Berdasarkan analisis Mustafa Abdullah, pertanggungjawaban dalam UU Pokok Pers itu menganut tanggung jawab dalam arti suksesif, sebuah pertanggungjawaban yang tidak lazim dalam sistem KUHP dalam hal publikasi yang menganut prinsip bahwa kesalahan harusnya diletakkan pada seseorang yang bertanggungjawab dalam publikasi (the presumption of guilt attaching to one another of the person concemed in the act publication) tanpa mempersoalkan apakah orang itu secara faktual adalah memang benar-benar penulisnya atau orang lain yang menulis. ${ }^{10}$

Selanjutnya ia menyatakan bahwa hukum pidana bertugas mencari pelaku tindak pidana sesuai dengan fakta, menentukan orang yang bersalah dengan kualifikasi bahwa orang yang benar-benar bersalah itu adalah yang mempunyai peranan paling besar dalam perbuatan tersebut."

Kinerja penyidik selama ini adalah secara kontinyu dihadapkan pada pola kriminalitas yang bersifat konvensional yang langsung dapat dikonfirmasikan dengan ketentuan yng ada dalam KUHP dan KUHAP. Baik dalam hal pertanggungjawaban maupun proses alur perkara menurut KUHAP sudah cukup jelas sehingga kinerja yang sifatnya rutinitas ikut menentukan pola penanganannya terhadap perkara. Demikian pula dalam kasus-kasus khusus seperti dalam tindak kriminal bidang ekonomi misalnya, perangkat hukum untuk itu juga sudah jelas dan dapat dikonfirmasikan hukum formalnya dalam KUHAP sedangkan hukum pidana materiilnya diatur dalam peraturan khusus dan atau dalam KUHP.

Terhadap kasus pengaduan yang muncul sebagai akibat pemberitaan pers menjadi tidak sederhana. Masalah hukum yang muncul sehubungan dengan pertanggungjawaban yang bersifat suksesif, yang harus segera disikapi oleh penyidik adalah apakah delegasi pertanggungjawaban itu dikenali sejak awal, ataukah setelah melalui proses penyidikan. Masalah ini penting untuk lebih efektif dan efisiensi kinerja penyidik. Dengan segera memanggil pihak yang secara pasti harus bertanggung jawab atas pengaduan, segera diketahui duduk soalnya dan penanganan selanjutnya. Dengan adanya politik keredaksian, akan sangat membantu dalam upaya menemukan pelaku sebenarnya dan oleh karena itu menjadi pihak yang paling bertanggung jawab atas pengaduan dari pihak yang merasa dirugikan.

Demikian pula ketika pemberitaan pers yang dianggap merugikan itu muncul, sementara pers hanya mengutip pernyataan seseorang, siapakah yang secara hukum menjadi pelaku utama - dan oleh sebab itu memikul tanggung jawab paling besar: sumber berita ataukah pers yang secara normatif sudah menerapkan prinsip kinerja

${ }^{9}$ Berdasarkan ketentuan yang dikeluarkan Dewan Pers pihak yang keberatan (misalnya penyidik atau penuntut umum) terhadap hak tolak wartawan dapat minta putusan tersendiri kepada hakim agar wartawan menyebutkan identitas sumber beritanya atau hak tolak tidak dapat dikenakan terhadap kasus tertentu.

${ }^{10}$ Mustafa Abdullah. Op. Cit. Hlm. 12.

$11 /$ bid. Hlm. 13. 
berdasarkan standar kelayakan berita? Konkritnya,siapakah yang bersalah, orang yang menyampaikan pernyataan ataukah wartawan yang mengutip pernyataan-pernyataan yang dijadikan bahan berita itu? ${ }^{12}$

Apabila kesalahan ada pada yang mengeluarkan pernyataan dan pers berposisi sebagai pembantu (deelnemer) itu artinya akan sama saja dengan kasus pembantuan biasa. Padahal pers dilindungi undang-undang secara khusus yang aktivitasnya dinilai berbeda dengan aktivitas cetak mencetak bisa yang pelanggaran hukumnya diatur dalam KUHP.

Dalam hubungan ini dapat dimaklumi jika penguasaan penyidik terhadap peraturan perundang-undangan tentang pers masih lemah ${ }_{1}{ }^{13}$ di samping ketidakberanian melakukan tindakan terhadap wartawan. Dalam konteks yang lebih umum ada keengganan jika harus menghadapi pers sebab bisa saja penyidik merasa "takut" bila pers disidik dan diproses menurut hukum itu akan menaruh dendam dan nantinya akan senantiasa mencari-cari kesalahan penyidik sendiri. Disadari bahwa kinerja penyidik pun tidak luput dari terjadinya kesalahan-kesalahan yang pada suatu ketika juga akan diketahui oleh pers. Apabila penyidik pernah "menyakiti" pers, maka hal yang sama juga akan dilakukan pers terhadap penyidik. ${ }^{14}$

Karena hal-hal di atas, ketentuan tentang pertanggungjawaban yang berimplikasi pada perlindungan hukum terhadap masyarakat itu sulit dioperasionalkan. Secara konseptual, pertanggungjawaban suksesif itu juga bertentangan dengan asas dalam hukum pidana bahwa siapa yang berbuat, maka ia yang harus memikul tanggung jawab atas akibat yang ditimbulkan oleh perbuatannya itu. Akibatnya perlindungan hukum terhadap masyarakat pun lemah. Masyarakat yang merasa dirugikan akibat pemberitaan pers tidak mempunyai bargaining position yang kuat sehingga sulit mengadukan pers akibat pemberitaan yang merugikan.

Oleh karena pertentangan inilah, konsep pertanggungjawaban yang bersifat suksesif tersebut ditinjau kembali (vide Pasal 12 dan Pasal 18 UU No. 40 Tahun 1999). Berdasarkan sistem di dalam undang-undang tersebut, tanggung jawab sebagai refleksi dari perlindungan hukum yang adil terhadap masyarakat diletakkan hanya pada penanggung jawab yang secara pidana mengacu kepada peraturan tentang hukum pidana yang masih berlaku.

Atas dasar sistem demikian, masyarakat yang merasa dirugikan akibat sajian pers dapat langsung menunjuk kepada penanggung jawab dari pers yang bersangkutan sebagai institusi yang disebutkan dalam undangundang. Hal inilah yang diprediksikan sebagai refleksi perlindungan hukum yang lebih baik.

\footnotetext{
${ }^{12}$ Sebelum UU Pokok Pers ada, pertanggungjawaban pidana diambil berdasarkan atas ajaran penyertaan (delneming) dan ajaran kesalahan (scheduler) setelah dipenuhinya 2 (dua) syarat: a. pelaku mengetahui isi dari tulisan yang masuk dalam surat kabar, dan b. pelaku sadar akan sifat pidana dari tulisan tersebut. $/$ bid. $\mathrm{Hlm}$ : 9 .

${ }^{13}$ Jawa Pos Minggu. 11 April 1998. HIm. 11.

${ }^{14}$ Wina Armada. Op. Cit. HIm. 93.
} 


\section{Simpulan.}

Perlindungan hukum berkait erat dengan pertanggungjawaban di dalam mekanisme kinerja pers. Berdasarkan UU No. 21 Tahun 1982 perlindungan hukum terhadap masyarakat akibat sajian pers masih lemah. Hal ini disebabkan oleh konsep pertanggungjawaban suksesif yang bertentangan dengan asas pertanggungjawaban dalam hukum bahwa siapa yang berbuat maka ia yang harus bertanggung jawab atas akibatnya.

Pertanggungjawaban suksesif dalam UU No. 21 tahun 1982 ditinjau kembali dalam UU No. 40 tahun 1999 yang mendeskripsikan tanggung jawab dengan menunjuk langsung kepada penanggung jawab. Operasionalisasi pertanggungjawaban itu didasarkan pada peraturan tentang hukum pidana yang berlaku. Dengan demikian perlindungan hukum terhadap masyarakat akibat sajian pers yang bermasalah lebih baik dibandingkan undangundang sebelumnya.

\section{Daftar Pustaka}

Abdullah, Mustafa. 1988. "Sistem Pertanggungjawaban Pidana Pers Menurut Hukum Positif Indonesia". Pidato Pengukuhan Guru Besar. Palembang: Fak. Hukum Univ. Sriwijaya.

Armada, Wina. 1993. Menggugat Kebebasan Pers. Jakarta: Pustaka Sinar Harapan.

Hadjon, Philipus M. 1987. Perlindungan Hukum Bagi Rakyat di Indonesia. Surabaya: Bina llmu.

Lubis, Mulya. 1986. "Realitas Hak untuk Mendapatkan Informasi dan Berkomunikasi di Indonesia". Hukum dan Pembangunan No. 4 Tahun XVI.

"Ombudsmen". Jawa Pos Minggu 11 April 1998.

Pacey, Arnold. 1983. The Culture of Technology. Cambridge Massachusetts: Published by the MIT Press.

Siregar, Ashadi. 1987. Ilusi Sebuah Kekuasaan. Surabaya: ISEI dan PUSHAM Ubaya.

Wahidin, Samsul. 1999. ‘Tanggung jawab Atas Pemberitaan Pers dalam Media Cetak". Disertasi. Surabaya: Program Pasca sarjana Unair. 